
www.globaljournalseries.com; Info@globaljournalseries.com

\title{
ICT AND TEACHERS' PERFORMANCE IN TERMS OF LESSON PREPARATION AND DELIVERY IN PRIMARY SCHOOLS IN OGOJA EDUCATION ZONE OF CROSS RIVER STATE, NIGERIA
}

\section{BERNARD ATROGOR OKO AND LOUISA UWATT}

(Received 9, January 2015; Revision Accepted 20, February 2015)

\begin{abstract}
This paper is a report of a study carried out to examine how information and Communication Technology (ICT) and teachers' performance in terms of lesson preparation and delivery in primary schools in Ogoja Education Zone of Cross River State, Nigeria. To achieve the purpose of the study, one research question was formulated to direct the study. Ex-post facto research design was adopted for the study .A sample of six hundred and twenty teachers was randomly selected for the study. The instrument for data collection was the ICT and Teachers' performance in lesson preparation and Delivery Questionnaire (ICTTPLIDO) Developed by the researcher. The reliability estimate of the instrument was established through the Cronbach alpha reliability method. Data collected were analyzed using simple percentage. The result of the analysis revealed that an enhancement of teachers' performance in lesson preparation and delivery through the use of Information and Communication Technology in Ogoja education Zone. Base on the findings of the study, it was recommended that government should provide computer at affordable price to all teachers in the Zone.
\end{abstract}

KEYWORDS: Teachers' performance, teachers' lesson preparation, teachers' lesson delivery in the primary school.

\section{INTRODUCTION}

Primary education has always been regarded as a vital level in Nation's education system especially as it is the first stage in the formal educational set up. Among the three tiers of education in the country, primary education is the stage patronized by a lot of learners. Whereas not all beneficiaries of primary education get to the other levels, the other beneficiaries of other levels of education mandatorily pass through primary school. The fact that it is the foundation of the whole education edifice underscores its importance (Oni, 2008).

The benefits of primary education cannot be overemphasized as it is a panacea for many problems including poverty, ignorance, squalor, religious bigotry and political servitude. Importantly too, government has for long known the benefits of primary education. This recognition has among other things motivated different governments to various occasions for a little more than half a century to make primary education free and proclaim it universal (oni, 2008).

In spite of the promises of education reforms, such reforms have often been either implemented haphazardly or abandoned at inception. For example, the 6-3-3-4 system of education which commenced in the early 1980s, most institutions could not effectively implement the introductory technology aspect due to lack of manpower, equipmennt, and lack of leadership. The computer education programme launched for secondary schools in 1988 never succeeded (Yusuf \& Yusuf, 2009). A study carried out by Jegede and Owolabi (2003) revealed that there is a wide gap between the policy and its implementation. Yusuf (2005) noted that most primary school teachers were not competent in basic computer operation and the use of generic

Bernard Atrogor Oko, Department of Curriculum and Teaching, University of Calabar, Calabar, Cross River State, Nigeria

Louisa Uwatt, Department of Curriculum and Teaching, University of Calabar, Calabar, Cross River State, Nigeria 
software.

\section{Literature review}

The use of ICT in teaching is a relevant and functional way of providing education to learners in order to assist them in imbibing the required capacity for the world to work (KosokoOyedeko \& Tella, 2010). Danies (2009) posited that teachers use ICT to prepare for lessons and to deliver lesson in class. For lesson preparation, the following are the common pattern of ICT use. Teachers search the internet: download relevant materials; design practice activities with word processing, prepare presentations with Microsoft Powerpoint. However, for classroom teaching, Powerpoint presentation is popular. Teachers use the internet to supplement teaching points. Word processing is also used especially for writing classes, while voice recording is sometimes used for recording students' presentation or for pronunciation practice.

Inevitably, computers were never developed for improving the quality of the teaching learning process, however, researchers started using computers for teaching purposes. This gave birth to computer Assisted instruction (CAI), Computer Managed Instruction (CMI), computer Based Instruction (CBI), etc. People started developing CAI for teaching different subjects at the primary school and at the higher education level (sansanwal,2009).

The developed CALs were compared with the lecture and Traditional methods and were found to be significantly superior to lecture and Traditional methods of teaching different subjects (prabliakar, 1995). Surprisingly, the traditional Method of teaching was found to be more effective in comparison to CAI (park, 1990; clem, 1998). However, the model of supplemented CAI was found to be effective in improving educable mentally handicapped students' achievement in Mathematics and spelling (Aukney, 1987).

It was also found out also that language impaired children benefited from written format like, dialogue with a computer (Ward, 1987). Again setting learning instructions, accessing information to accomplish the task, and evaluating performance benefited students with learning disabilities when they were engaged in CAl activities (McPherson, 1991). Order adults however, successfully used the computer and were able to improve their knowledge about health with a CAI lesson (McNeely, 1988). CAI was effective in language acquisition (Edfelt, 1989) and teaching abbreviation (Edward, 1989). CAl had a positive impact on reading and comprehension for average readers but not for the disabled readers (Traham, 1989).
The CAI Tutorial Retrieval Text and Programmed Lecture were equally effective in promoting learning (Whitaker, 1990). CAl was found to be effective in terms of achievement of science process skills (Vensel, 1988) as well as increasing meta-cognitive in teaching reference skills (Bonk, 1990), it was also found to increase the rate of acquisition of school readlines skills of pre-school children (Legenhausen, 1991), and in improving writing skill (powell, 1992).

In spite of the benefits of CAl as outlined above in different aspect of learning, CAl is yet to be fully incorporated into the classroom as most of the developed CAI were not having the sound thrones of learning. People involved in developing CAl were not having the sound base of instructional Design. Also the courses are changing and the schools do not have sufficient computer facilities coupled with teachers who are not trained in the testing, evaluation, database management, library management etc. (Sausauwal,2009).

Besides, ICT is known to open new avenues, like online learning e-learning virtual university, e-coaching, e-education, e-joumal etc. ICT is known also to bring more materials in the classroom and lobrawes for the teachers and student. It has provided opportunity for the learner to use maximum senses to get the information. It has broken the monotony and provided variety in the teaching-learning situation. ICT can be used both at the primary school and higher education levels in the following areas:

- Teaching

- $\quad$ Diagnostic Testing

- $\quad$ Remedial Teaching

- $\quad$ Evaluation

- $\quad$ Psychological Testing

- $\quad$ Development of Virtual Laboratory

- Online Tutoring

- $\quad$ Development Reasoning and Thinking

- Instructional Materials Development (sansanwal, 2009).

\section{Theoretical background}

It is necessary that one has an insight in to the background of theories that support a particular study and from where the problem may be identified and hypothesis formulated. The researcher examines ICT-oriented micro model since the study dealt with ICT and teachers' performance in terms of lesson preparation and delivery.

Reiber and Welliver (1989) and later Marcinkicwicz (1994) developed the instructional transformation model which has been used by a number of researchers in the likes of Knee (1996) to help schools design their restructuring plan using technology. This model 
was developed from a study of adoption behaviour drawing on the CBAM model and the work of Rogers (1983). This saw much value to educators in the model, particularly in recommending staff, development, remediation, or differential staffing (Marcinkiewick \& Welliver 1993). The instructional transformation model proposes a hierarchy for the successful application of technology to education using levels of use (LOU) type of approach. This hierarch involves the following four steps:

i. Familiarization

ii. Utilization

iii. Integration

iv. Re-orientation

These stages show that an educator has to progress through different steps in order to correspond to apple classrooms of Tomorrow (ACOT) stages which begging with the period of familiarity (Entry) representing baseline exposure to technology; utilization (Adoption) occurring when teachers try the technology, integration (Adaption) beginning the appropriate use of ICT, reorientation (Appropriation) where ICT becomes a part of the learning context and evolution or revolution (invention) where there is a change in methods and media to facilitate learning. These stages are confirmed in longterm project like the Apple Classrooms of Tomorrow (ACOT, 1995) studies which show that teachers must travel through a number of stages to integrate ICT fully into their classroom and their teaching programmers and teaching must progress through all five phases otherwise, the technology will likely be misused or discarded (Rieber \& Welliver, 1989: Marcinkiewicz, 1994).

Moersch (1997) has reported his development of levels of Technology Implementation (LOTI) framework which defines seven levels of the implementation of computers in a school. The levels are based on the original CBAM levels and are called: nonuse awareness, exploration, infusion,integration (mechanical), interaction routine, expansion and refinement. From this framework, Moersch (1997) developed an instrument to calculate what he refers to as the computer efficiency at a school site. Computer efficiency is the degree to which computers are being used to support concept-based instruction, consequential learning, and higher order thinking skills. The instrument accumulates the products of the LOTI level proportion of computer use, proportion to arrive at the levels (Hall and Hors, 1987).

Student use computers to produce an index for comparison between schools. However. The originators of concern-based models would not approve of such an instrument since it uses a questionnaire rather than observation and interview and uses numerical calculations to arrive at levels (Hall \& Hord, 1987).

\section{Research question}

How does ICT enhance teacher's performance in terms of lesson preparation and delivery in Ogoja Education Zone?

\section{Design methodology}

The research design adopted for this study is the ex-post facto design because the researcher has no direct control of the independent variable as their manifestation had already occurred. The study was carried out in Cross River State, Nigeria. The population was made up of primary school teachers in Ogoja education Zone totaling 4,473 in 415 schools.

The sample for this study consisted of six hundred and twenty (620) teachers randomly selected from 62 primary schools in Ogoja Education Zone of Cross River State. A breakdown of the figure shows that teachers were selected from each of the sixty-two (62) primary schools sampled for the study.

A further breakdown of the figure as shown in Table 1 reveals that 100 teachers were selected from Bekwarra Local Government Area, 120 teachers from Obanliku Local Government Area, 120 from Obudu Local Government Area, 130 teachers from Ogoja Local Government Area and 150 teachers from Yala Local Government Area respectively.

TABLE 1: Distribution of sample by local government

\begin{tabular}{|l|l|l|}
\hline LGA & NO OF RESPONDENTS & PERCENTAGE \\
\hline Bakwarra & 100 & 16.13 \\
\hline Obanliku & 120 & 19.35 \\
\hline Obudu & 110 & 17.74 \\
\hline Ogaoja & 130 & 20.97 \\
\hline Yala & 150 & 24.19 \\
\hline Total & 620 & 100 \\
\hline
\end{tabular}




\section{DATA ANALYSIS/DISCUSSION}

How does ICT enhance teacher's performance in terms of lesson preparation and delivery in
Ogoja Education Zone? The data were analyzed using simple percentage in answering the research questions, the result is presented in Table 2.

TABLE 2: Result of responses of the respondents on how ICT enhance teachers performance in terms of lesson preparation and delivery in Ogoja Education Zone

\begin{tabular}{|c|c|c|c|c|c|c|}
\hline $\mathrm{S} / \mathrm{N}$ & & ITEMS & $\begin{array}{l}A \\
\%\end{array}$ & $\mathrm{~F}$ & $\begin{array}{l}\text { RESPC } \\
\text { D } \\
\%\end{array}$ & $\begin{array}{l}\text { NSES } \\
\text { Total } \%\end{array}$ \\
\hline 1. & $\begin{array}{l}\text { I discover additional teaching } \\
\text { Techniques through my interaction } \\
\text { With the internet. }\end{array}$ & 241 & 38.87 & 379 & 61.13 & 620100 \\
\hline 2. & $\begin{array}{l}\text { My lesson content is enriched } \\
\text { through } \\
\text { additional information from the } \\
\text { internet. }\end{array}$ & 200 & 32.26 & 420 & 67.74 & 620100 \\
\hline 3. & $\begin{array}{l}\text { I have greatly improved my class } \\
\text { Presentation ability with ICT }\end{array}$ & 232 & 37.42 & 388 & 62.58 & 620100 \\
\hline 4. & $\begin{array}{l}\text { I have acquire new techniques } \\
\text { Through the information and } \\
\text { Communication technology. }\end{array}$ & 301 & 48.55 & 319 & 51.45 & 620100 \\
\hline 5. & $\begin{array}{l}\text { I have acquire knowledge on } \\
\text { modern instructional materials } \\
\text { and how to use } \\
\text { them for teaching. }\end{array}$ & 250 & 40.32 & 370 & 59.68 & 620100 \\
\hline
\end{tabular}

The result in Table 1 revealed that for item 1.241 (38.87) of the total respondents agreed that they discover additional teaching techniques through their interaction with the internet, while $379(61.13 \%)$ disagreed. For item 2, $200(32.26 \%)$ agreed that their lesson contents enriched through additional information from the internet, while $420(67.74 \%)$ disagreed. For item $32,320(37.42 \%)$ agreed that they have greatly improved their class presentation ability with ICT facilities, while $388(62.58 \%)$ disagreed. For item 4,301 (48.55\%) agreed that they have acquired new techniques through the information and communication technology, while $319(51.45 \%)$ disagreed. For item 5,250 $(40.32 \%)$ agreed that they have acquired knowledge on modern instructional materials and how to use them for teaching, while 370 $(59.68 \%)$ disagreed. Discussion of findings.

The findings of this research question is in agreement with the view of Danies (2009) who posted that teachers use ICT to prepare lesson and to deliver lesson in class. For lesson preparation, the following are the common pattern of ICT use :Teachers search the internet, download relevant materials; design practice activities with word processing, prepare presentations with Microsoft PowerPoint. However, for classroom teaching PowerPoint presentation is popular. Teachers use the internet to supplement teaching points. Word processing is also used especially for writing classes, while voice recording is sometimes used for recording student's presentations or for pronunciation practice.

The computers were never developed for improving quality of teaching -learning process. But researchers started using computers for teaching purposes. It gave birth to Computer Assisted Instruction (CIA), Computer managed Instruction (CMI), Computer Based Instruction (CBI), etc. People started developing CAl for teaching different subject at the primary school as well as Higher Education Level (Sansanwal, 2009)

The developed CALs were compared with the lecture Method/Traditional Method and found that the developed CALS were significantly superior to lecture Method/Traditional Method in teaching different subjects (Prabliakar, 1995). Furthermore, the traditional Method of teaching was found to be more effective in comparison to CAl (Park, 1990; Clem, 1998). However, the model of supplemented CAI was found to be effective in improving educable mentally handicapped student's achievement in mathematics and spelling (Aukney, 1987).

Ward (1987) also found out that language impaired children benefited from little 
format like, dialogue with a computer. Setting following instruction, accessing information to accomplish the task, and evaluating performance benefited students with learning disabilities when they were engaged with CAI activities. McPherson (1991) also stated that older Adults however successfully used the computer and were able to improve their knowledge about Health with CAl lesson (McNeely, 1988). CAl was effective in language acquisition and teaching abbreviation. CAl had a positive impact on reading comprehension for average reader but not for learning disabled readers.

\section{CONCLUSION/RECOMMENDATION}

Based on the findings of the study, the following recommendations are made:

Government should provide computers at affordable prices to all the teachers in the educational Zone.

Teachers should organize or create awareness on information and communication Technology (ICT) to enhance the student.

Government should provide necessary facilities that would guard against the constraints facing the use of ICT.

\section{REFERENCE}

ACOT., 1995. Changing the conversations about teaching. Learning and technology: A report on 10 years of ACOT research. Frenchs forest, NSW: Apple computer Australia.

Ankney, B. R., 1987. The use of computer Aided instruction with Educable Mentally Handicapped students. Implication for Administrative Decision making Dissertation Abstract International, 49, (3):

Bonk, E., 1987. The effects of Generative and evaluative computerized prompting strategies on the development of children's writing awareness and performance. Dissertation abstract international, 51, (3):

Clem, E., 1990. An analysis of the effect of computer and non-computer tutorial programmes on the academic achievement of high school junior students in a selected school district in a southeast Taxas. Dissertation Abstract International, 51, (7):

Davies, S. H., 2009. Introduction to new technologies and how they can contribute to language learning and teaching. Module 1.1 in G. Davies (ed.) information and communications technology for language Teachers (ICT4LT), slough, thames Valley University (online).

Edfelt, N. M., 1989. Computer Assisted second language acquisition: the Oral source of children at the computer in a cooperative context. Dissertation Abstract International, 50, (4):

Edward, B. J., 1989. The effects of a computer assisted instruction program using the constant time delay procedure to teach spelling of abbreviation to adolescent with mild learning handicaps. Dissertation Abstract International, 50 (9).

Hall, G. E and Hord, S. M., 1987. Change in schools facilitating the process. Albany: state University of New York press.

Jegede, P. O., Owolabi, J. A., 2003. Computer education in Nigerian Secondary schools. Gaps between policy and practice Meridian 6(2) (on-line) Retrieved November 23 2014 from http://www.ncsu.edu/meridian/sum2003/ nigeria/index.html

Knee, R. H., 1996. The relationship of selected principal characteristics to the integration of technology in schools. Unpublished doctoral thesis, Florida Atlantic University.

Kosoko-Oyedeko, G. A and Tella, A., 2010. Teachers' perception of the contribution of ICT to pupils performance in Christian Religious Education. Journal of social Science, 22, (1): 7-14.

Legenhausen, E. I., 1991 effectiveness of instruction using a microcomputer equipped with LOGO microwords on the acquisition of school readiness skills by preschool children. Dissertation Abstract International,52, (6):

Marcinkiewicz, H. R., 1994. Computer and teacher: Factors Influencing Computer use in the Classroom. Journal of Research in Computing Education, 26, (2): 220-237.

McNeely, E. A., 1988 computer assisted instruction: A health education strategy for the older adults. Dissertation Abstract International, 49, (10):

Mcpherson, S. J., 1991. The effects of metacognitive strategy training with computer 
assisted instruction for vocabulary acquisition by students with learning disabilities. Dissertation Abstract international, 52, (6):

Moersch, C., 1997. Computer efficiency. Measuring the instructional use of technology Learning and leading with technology. (December), 11-16.

Oni, K. C., 2008. Agro-industrialization on National food security: issues constraint and strategies. Plenary paper presented at the $32^{\text {nd }}$ Annual conference and general meeting at NIFST, LANTECH, 2008.

Park, J. S., 1990. The effect of computer Assisted Instruction in Teaching Reading Adult Basic Education student. Dissertation Abstract International, 51, (11):

Powell, B. L., 1992. The improvement of writing skills of college freshmen through computer based instruction. Dissertation Abstract International, 53, (1):

Prabhakar, S., 1995. Development of software for computer aided instruction and its comparison with traditional method for teaching physics at plus ii level. Ph.D. (Edu.), Devi Ahilya University.

Rieber, L. P and Welliver, P. W., 1989. Infusing Educational technology into mainstream educational computing. International journal of instructional media, 16, (1): 21-32.

Rogers, E. M., 1993. Diffusion of innovations $\left({ }^{2 e d}.\right)$. New York: The free press.
Rogers, E. M., 1985. Diffusion of innovations ( $4^{\text {th }}$ ED.), New York: The free press.

Sansawal, D. N., 2009. Use of ICT in teachinglearning and evaluation New Delhi: central Institute of Educational Technology.

Trahan, M. F., 1989. The effect of computer delivered science simulations on the acquisition and reading comprehension of average and learning disabled riders. Dissertation Abstract International, 51, (1):

Vensel, G. J., 1988. The effectives of computer delivered science simulations on the acquisition of process skills for gift and general population fourth and fifth grades. Dissertation Abstract International, 49, (10):

Ward, R. D., 1987. Natural language computer assisted learning and language impaired children. Dissertation Abstract International, 49, (10):

Whitaker, D. C., 1990. Comparison of tutor retrieval text, computer assisted instruction, and programmed lecture in teaching statistics to physical education majors. Dissertation abstract international, 51, (11):

Yusuf, M., 2005. Information and Communication Technology and Education: Analyzing the Nigeria policy for Information Technology. International Education Journal 6, (3): 316-321. 